研究

ホットプレスで作製した Mo/PSZ 系焼結複合材料の熱・機械的性質の異方性

\author{
山田葉子的，渡辺 龍三々1，江莞々2 \\ 出 1 東北大学工学部材料加工学科, $\mathbf{T} 980-77$ 仙台市青葉区荒巻字青葉.

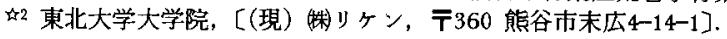

\title{
Analysis of Anisotropic Thermomechanical Properties of Mo/PSZ Composite Produced by Hot Pressing
}

\author{
Yoko Yamada ${ }^{\text {1 } 1}$, Ryuzo Watanabe ${ }^{\text {1 } 1}$ and Wan Jiang ${ }^{\natural 2}$ \\ t5 Department of Materials Processing, Faculty of Engineering, Tohoku University, Aoba-ku, Sendai 980-77. \\ Graduate School, Tohoku University, [Present Address: Riken Corporation, 4-14-1 Suehiro, Kumagaya 360].
}

Received August 8, 1995

\section{SYNOPSIS}

The effect of fiber orientation on the thermal expansion coefficient, the Young's modulus and the thermal conductivity of hot pressed Mo / PSZ composites was studied both experimentally and theoretically. The fiber orientation of the hot pressed Mo / PSZ composites was determined by optical microscopic observations on their cross-sections. In order to make a theoretical analysis of the above mentioned properties on the basis of Eshelby's equivalent inclusion method, the measured fiber orientation distributions were converted to polynomial functions. Compared with the conventional procedure using cosine or uniform distribution functions for the fiber orientation, the polynomial distribution function gave predictions which were in good agreement with the experimental.

\section{KEY WORDS}

thermal expansion coefficient, Young's modulus, thermal conductivity, fiber orientation distribution function, dispersion strengthened composite

\section{1 緒 言}

ホットプレス法は HIP (熱間等方圧成形) と亚ぶ加圧娔 結法の基本型の一つである，この焼結法は材料を高温下 で高圧を加えながら製造するために，融点が高く焼結が 困難であるセラミックス等も容易に緻密化できるという 特長を持つ.そのため実験室レベルで最も多く用いられ ている焼結法の一つである。しかし，この方法には，(1) 得られる複合材料の寸法が装置の能力により制限されれ ろ，(2) 娔結体形状が板状の物に限られる，(3)一方向加 圧のために分散相が特定の配向をもち易く複合材料等の 場合，特性に強い異方性が生じやすい，などの欠点があ ろ. 特に(3)のように材料組織の異方性のためにその特性
に異方性が生じる場合には，材料設計の自由度が小さく なり，目的とする熟・機械的性質を持つ材料を得るため の妨げになる．したがって，ホットプレス材における組 織の配向性と材料特性の異方性の関係を明らかにする必 要がある。

本研究では耐熱性や耐エロージョン性を持ち熟衝撃に も強いMo/PSZ系焼結複合材料に着目し，本材料のホッ トブレス焼結体における分散粒子配向性に起因する熟. 機械的性質の異方性を測定した。ざらに焼結時に生じた 租織の配向性が複合材料の熟・機械的性質に及はす影豊 を理論的に険討するために，定量化した組織の配向分布

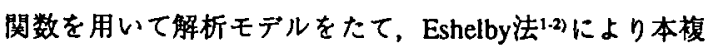


合材料のヤング率，熟脚張係数，熟伝導率の異方性を解 析した.

\section{2 試料および実験方法}

\section{1 試料作製}

原料粉末は, 平均粒径 $0.07 \mu \mathrm{m} \sigma \mathrm{ZrO}_{2}-3 \mathrm{~mol}_{2} \mathrm{Y}_{2} \mathrm{O}_{3}$ 粉

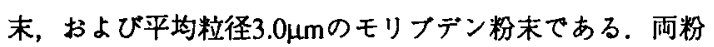
末をへキサン中でボールミルにより $6 \mathrm{~h}$ 混合し，ジルコニ アを20，40，60，80vol\%含む混合粉を得た。あらかじめ 金型ダスを用いて 150MPa で予供成形した後，200MPa で静水圧成形を行った．成形体を黒鉛型に装填し，真空 中 $1773 \mathrm{~K}, 30 \mathrm{MPa}$ で $60 \mathrm{~min}$ ホットプレスした.

\section{2 組織の配向性評価}

ホットプレスで作製しだ試料の熟・機械的性質の異方 性を調べるために，作製した試料の組織の配向性を評価 した. 組織の異方性バラメータは, 試料の研磨面の光学 顕微鏡組織を画像処理装置内に取り込み解析することに より揤定した．分散粒子のアスペクト比は，分散粒子の 重心のまわりの慣性モーメントが等しい棈円を求め，そ の榇円の長軸と短軸の長さの比とした、また分散粒子の 傾きは，ホットプレス荷重方向に対する棈円の長軸の傾 きをもって分散粒子の傾き日とした。

\section{3 熟・機械的性質の測定方法}

ヤンダ率はLFB（Line Focus Beam）超音波顕微鏡による 表面波音速測定法で測定しだ)。装置は本多電子(株)製 HMS-300V を一部改造したもので，200MHz LFBレンズ による V(z) 曲線解析法を用いた音速, 減衰の定量計測機 能を持っている。ナング率は，まず漏洩弾性表面波 (LSAW: Leakey Surface Acoustic Wave) と柱波成分の強い 漏洩弾性表面波 (LSSCW: Leakey Surface Skimming Compressional Wave）の 2 種の伝播モードの波を測定し，これ らの音速（LSAW の音速: $C_{L}$ ， LSSCW の音速: $C_{R}$ ) を解 析する.そして求めた值を次式に代入してボアンン比vを 求め,

$$
\begin{gathered}
\left(2 C_{R}^{2}-2.509 C_{L}^{2}\right) v^{3}+\left(2 C_{R}^{2}-2.643 C_{L}^{2}\right) v^{2} \\
+\left(0.4350 C_{L}^{2}-2 C_{R}^{2}\right) v+\left(0.7569 C_{L}^{2}-2 C_{R}^{2}\right)=0
\end{gathered}
$$

得られたvを式(2) または (3)に代入することにより，局 所領域のヤング率Eが求められる゙.

$$
\begin{aligned}
& E=\rho C_{R}^{2} \frac{2(1+v)^{3}}{(0.87+1.12 v)^{2}} \\
& E=\rho C_{L}^{2} \frac{(1+v)(1-2 v)}{1-v}
\end{aligned}
$$

ここで $\rho は$ 試料の密度である，音速は組織の局所的不均 一による影留を排除するために位置を変えて 5 点测定し その平均值を用いた，測定周波数は $215 \mathrm{MHz}$ てある。
熟膨張係数の測定はレーザスペックル法で行っだ7. これは物体表面にレーザ光を照射し，表面の微細な凸凹 による散乱光の不規則な位相干涉によって形成される粒 状模様 (スベックルパターン)を1枚の写真乾板に 2 重管 光し，この乾板に再度同じレーザを照射することによ り，得られる変位方向に垂直なヤングの干渉縞の間隔か ら試料の変位を測定する方法である゙。

熱伝導率は、レーザフラッシュ法により測定した熱拡 散率 $\delta$ と热容量 $C_{\mathrm{p}}$ から次式を用いて求めた。

$$
K=\delta C_{\mathrm{p}} \rho
$$

測定に使用した装置は日本真空技術株式会社製の Laser Constant Analyzer TC-7000である，熱拡散率は，断熟状態 にあるディスク状試験片の表面をレーザビームで瞬間的 に一様加熱し，裹面の温度が最終到達温度の $1 / 2$ に達す

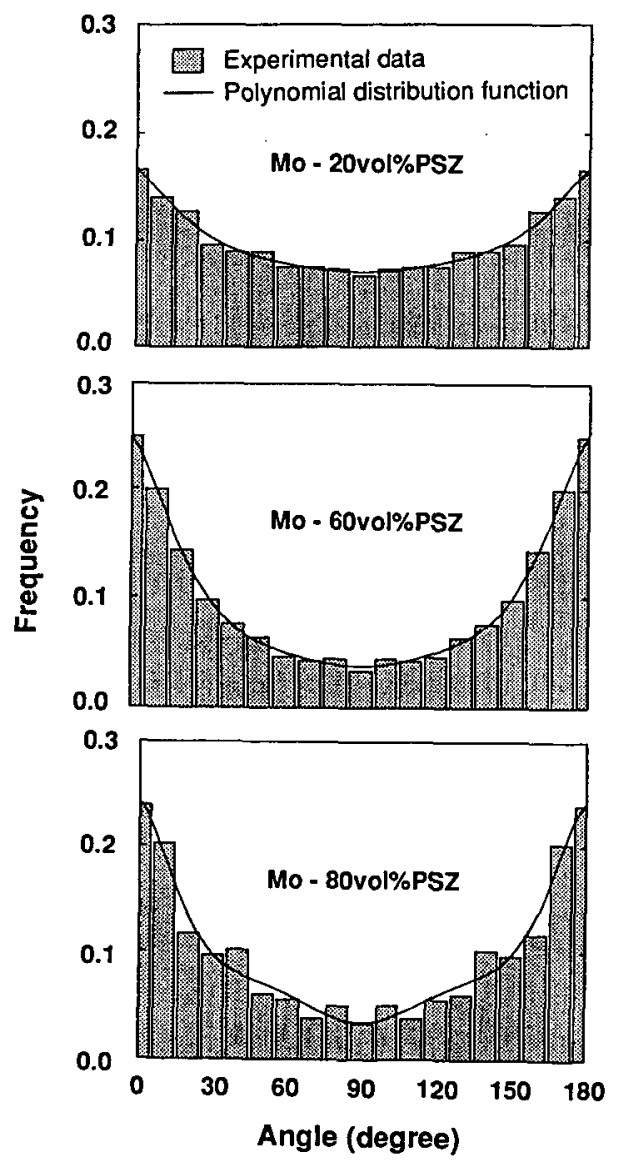

Fig.1 Experimentally determined fiber orientation distribution and calculated polynominal distribution function. 
るまての時間 $t_{12}$ から, 次式より求めた.

$$
\delta=1.37 L^{2} /\left(\pi^{2} t_{1 / 2}\right)
$$

ここでしは試験片の厚さである，比熱はレーザフラッ シュを照射した試験片婁面の温度変化 $\Delta T_{\text {max }}$ ，およびレー ザバルス熟源により与えられた栐量を熟容量既知の標準 試験片により校正した熱量 $Q$ から，次式より算出した。

$$
C_{\mathrm{p}}=Q /\left(\rho L \Delta T_{\max }\right)
$$

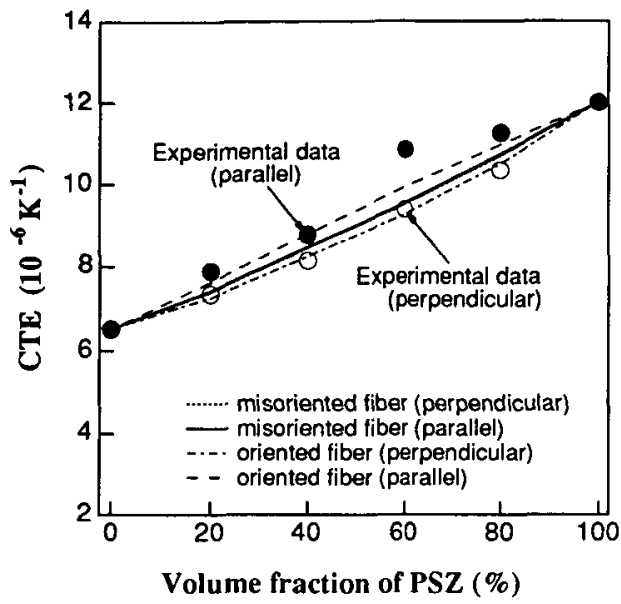

Fig.2 Predicted and experimental thermal expansion coefficients of Mo / PSZ composites both in parallel and perpendicular to hot pressing directions. Predicted data are calculated from considering or ignoring the misorientation of dispersed particles.

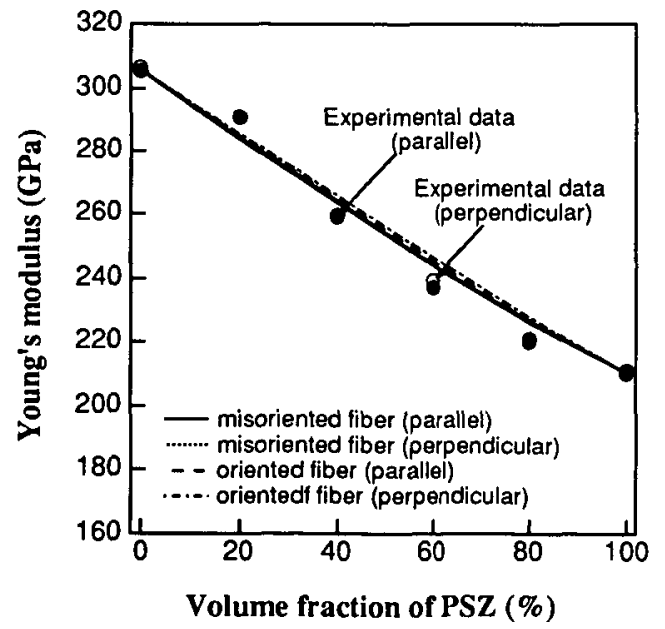

Fig.3. Predicted and experimental Young's moduli of $\mathrm{Mo} /$ PSZ composites parallel and perpendicular to hot pressing direction. Young's modulus is measured using a scanning acoustic microscope.

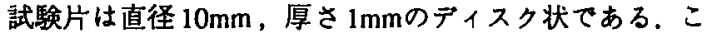
のサイズの試験片はホットブレス荷重に垂直方向のみ探 取可能のため，熟伝導率はこの方について測定した。

\section{3 実験結果}

作製した複合材料組織の分散粒子配向性の测定結果を Fig.1に棒グラフで示す.ホットブレスで作製したため分 散粒子が荷重方向に対して垂直方向に幾分整列し，複合 材料組織に配向性が生じていることがかかる。

Fig.2〜4 にはそれぞれ熹彫張俰数、ヤング率，熟伝導 率の測定結果を示す．黒丸はホットブレス荷重に平行方 向、白丸は垂直方向の結果である、試験片形状の都合 上，熱伝導率は平行方向のみ測定されている。ヤング率 にははとんど異方性が現れなかったが，熱膨張係数は全 組成においてホットプレスに平行方向の方が垂直方向に 比べ大きな値を示した。

\section{4 理論解析および考察}

\section{1 分散組織配向性の定量化}

複合材料の組織の異方性がその熟・機械的性質の異方 性に与える影響を理論的に調べるため，本研究ではFig.1 に示した複合材料の分散相の配向分布の定量化を試み た.これまで分散相の配向性が複合材料の熟・機械的性 質に及はす影響を解析するためにその配向分布を定量化 した研究は数多くあるが，いずれの場合にも配向分布を 一方向分布やランダム配向，コサイン分布等の関数に置

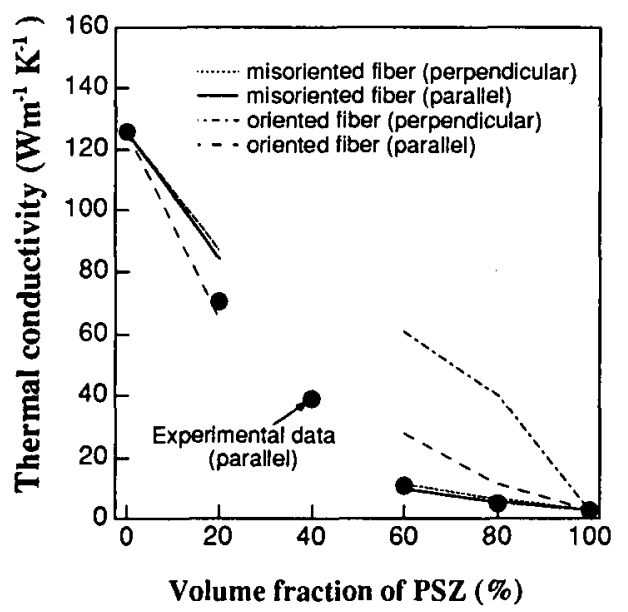

Fig.4. Experimental and predicted thermal conductivities of Mo / PSZ composites at parallel and perpendicular to hot pressing direction. Predicted data are calculated from considering or ignoring the misorientation of dispersed particles. 


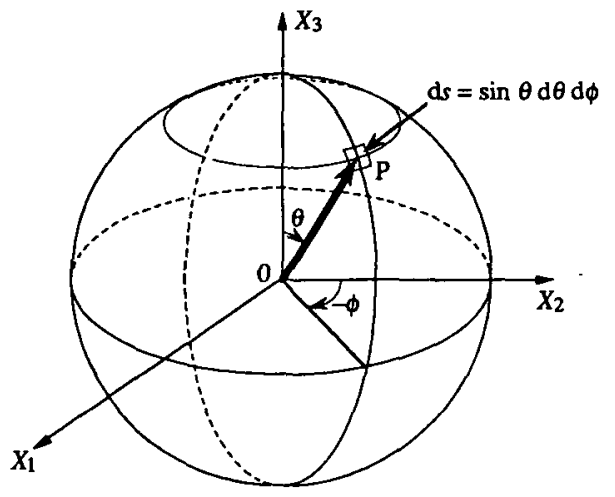

Fig.5 Fiber orientation space.

き換えていろ ${ }^{2-9}$. ところが実際の複合材料の分散相の配 向分布は, Fig.1からもわかるように必ずしもこのような 分布関数をとらない，そこで本研究では奏際の分散相配 向分布にできるだけ近い分布関数を得るために，測定し た分散相の配向分布を次式に示す 9 次の多項式分布関数 に定量化した。

$\rho(\theta)=m_{0}+m_{1} \theta+m_{2} \theta^{2}+m_{3} \theta^{3}+\cdots+m_{8} \theta^{8}+m_{9} \theta^{9}$

Fig.1の曲線に関数化した配向分布曲線を示し，各組成こ との多項式分布関数の係数は次に示す.

Mo - 80vol\%PSZ

$$
\begin{aligned}
& m_{0}=0.24206381425, \quad m_{1}=-0.098165950306 \\
& m_{2}=-1.8116627786, \quad m_{3}=-5.3179929148 \\
& m_{4}=-6.7752300828, \quad m_{5}=4.6091306172 \\
& m_{6}=-1.7327930412, \quad m_{7}=0.33932293079 \\
& m_{8}=-0.02699713121, \quad m_{9}=-7.1088030779 \times 10^{-7} \\
& \text { Mo - 60vol\%PSZ } \\
& m_{0}=0.25006867646, \quad m_{2}=-0.16610685652 \\
& m_{2}=-1.1452057773, \quad m_{3}=3.1495072855 \\
& m_{4}=-3.7103111632, \quad m_{5}=2.3930434529 \\
& m_{8}=-0.87315060053, \quad m_{7}=0.16894253929 \\
& m_{B}=-0.013441252619, \quad m_{9}=-3.6917558905 \times 10^{-7} \\
& \text { Mo - 20vol\%PSZ } \\
& m_{0}=0.16541898224, \quad m_{1}=-0.074853186754 \\
& m_{2}=-0.44590138629, \quad m_{3}=1.2435547681 \\
& m_{4}=-1.4851513479, \quad m_{5}=0.96905014739 \\
& m_{6}=-0.3560610469, \quad m_{7}=0.069089958127 \\
& m_{8}=-0.0054968902046, \quad m_{9}=-1.4858593130 \times 10^{-7}
\end{aligned}
$$

ここで実験値から上式への近似は最小二乗法で行った. また，PSZを80および60vol\% 含む組成ではMoを分散 相，PSZを $20 \mathrm{vol} \%$ 含む組成ではPSZを分散相とした。一 方PSZを40vol\% 含む組成ではMo, PSZともに互いに連結 したネットワーク組織であるため，分散相を仮定した Eshelby法による理論解析からは除外した.ここで，求め
た多項式分布関数曲線の全角度での皘分は1になること から，各組成毎に式 (8) 一(10) を入力した分布関数 $p(\theta)$ に，以下に示した定数 $\mathrm{k}$ を乗ずる必要がある。

$$
\begin{array}{ll}
k=1.16304 & \text { (Mo - 80vol\%PSZ) } \\
k=1.21059 & \text { (Mo-60vol\%PSZ) } \\
k=0.93839 & \text { (Mo-20vol\%PSZ) }
\end{array}
$$

これらの值を式(7)に代入すると，粒子の配向性を考虑し た配向密度分布関数を求めることができる。

\section{2 熱膨張係数}

Eshelby の等価介在物法は，分散相が回転楕円体の場合 に限り分散相内部に発生するひずみが一定になるという 実証に基づき，すべての分散相を回転棈円体で近似して いる，そのため，そのアスペクト比を変化させることに より粒子やウィスカ，長械維など様々な分散相を扱うこ

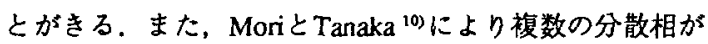
分散する場合の分散相同士の相互作用の影響についても 解かれているため，複合材料の3 次元的解析方法として 広範な応用䈥囲を持つ。こではこのEshelby 法を用いて 本複合材料の熱・機械的性質の異方性を解析し実験值と 比較険討することにより，これらの挙動の理論的解明を 試みた。

複合材料全体の熱膨張係数 $\alpha_{c}$ は微量温度変化 $\Delta T$ 当た

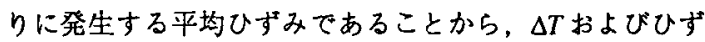
みの体積平均 $\gamma^{D}$ を用いて $\alpha^{c}=\gamma^{D} / \Delta T$ のように表され る.ここで $\gamma^{D}$ は次式のように表される.

$$
\gamma^{D}=\alpha^{m} \Delta T+\left.\frac{1}{V_{D}}\right|_{\Omega} e^{*} \mathrm{~d} V
$$

ここで $\alpha^{m}$ はマトリックスの熟胿張係数，VDは複合材料の 体積， $\Omega$ は分散相領域である。また $e^{*}$ は eigenひずみと 呼ばれ，マトリックスと分散相の效膨張係数差により熹 沁力が発生した場合，次式に示すEshelby法により導かれ る分散相内部の応力とひずみの関係式から求められる.

$$
\begin{aligned}
\sigma_{i j} & =C_{i j k l}^{f}\left(\bar{e}_{k j}+e_{k j}-e_{k j}\right) \\
& =C_{\text {jkj }}\left(\bar{e}_{k j}+e_{k j}-e_{k j}{ }^{j}\right)
\end{aligned}
$$

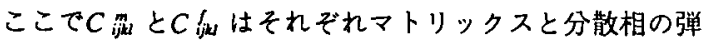
性定数， $\sigma_{i j}$ と知はそれぞれ分散相の存在によって乱さ

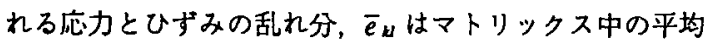
ひずみ，e死はマトリックスと分散相の熱澎張係数差によ り発生するひずみである. プライムは各々の分散相の回

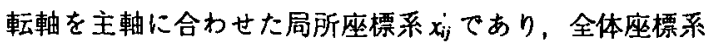
$x_{\operatorname{mon}}$ との方向余弦 $C_{\mathrm{im}}$ を用いて次式のように変換できる.

$$
x_{i j}=C_{i m} C_{j n} x_{n n}
$$

ここで 3 次元軸対象の場合，方向余弦はFig.5に示した空 間座標を用いて次式のように表される。ここではx 方向 
がホットブレス方向であ。

$$
C_{i j}=\left[\begin{array}{ccc}
\cos \theta \cos \phi & \cos \theta \sin \phi & -\sin \theta \\
-\sin \phi & \cos \phi & 0 \\
\sin \theta \cos \phi & \sin \theta \sin \phi & \cos \theta
\end{array}\right]
$$

式(12) で求めた $e$ を式(11)に代入することにより複合材

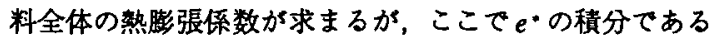
$\left\langle T_{i}^{*}\right\rangle_{0}$ には分散相の配向密度分布関数が含まれており， それらの関係は次式のように表される。

$$
\begin{aligned}
\left\langle e_{i}^{*} b\right. & =\frac{1}{V_{f} V_{D}} \int_{\Omega} e_{i}^{*} \mathrm{~d} V \\
& =\int_{0}^{2 \pi} \int_{0}^{\pi} e_{i}^{*}(\theta, \phi) \rho(\theta, \phi) \sin \theta \mathrm{d} \theta \mathrm{d} \phi
\end{aligned}
$$

$\rho(\theta, \phi) に$ 各組成について求めた式(7)を代入すると，分 散相の配向性の効果を含んだ eigenひずみを求めることが でる。

Fig.2の曲線は、ホットプレス荷重方向に平行および垂 直方向の熟胿張係数の解析結果である．焼結組織の異方 性には分散粒子のアスペクト比および分散粒子の傾きの 2つの要因があるが、ここではそれぞれの効果を区別す るために，分散粒子が一方向に配列した場合，および粒 子がホットプレス荷重方向に対して傾きを持つ場合の両 者についての解析結果を示してある，ここでは配向分布 として上記で求めた 9 次の多項式分布関数を用いた。解 析結果より，分散粒子のアスペクト比の変化が椱合材料 全体の熱膨張係数に及はす影響は大きく，分散粒子が一 方向に配列した最も異方性が強く現れた場合には，ホッ トブレスの荷重方向およびそれに垂直方向の熱膨張係数 に最大で $0.6 \times 10^{-6} / \mathrm{K}$ 以上の差が現れた。またホット ブレスに平行方向の熟膨張係数の方が垂直方向に比べ大 きくなることも理論的にも説明され，これは実験值と一 致している. 一方, 粒子の配向分布をモデルに取り込む と熟澎張俰数の異方性が小さくなる。これを実験值と比 較すると，荷重に平行方向の熱膨張係数の実験値は解析 結果よりも大きくなっており，その差はPSZを多く含む 組成側で増大している。しかし荷重に垂直方向について は解析結果と実験値は良く一致している。さらに，Moを 40vol\%含む組成では，実験值は解析結果とは異なり極め て大きな值になっている，この原因は本研究では解明す ることはできながったが, 荷重に平行および垂直方向の 解析結果を比較すると，本複合材料の場合には荷重に平 行方向の熟胿張係数の方が配向性などの組織の変化に強 く影都されている。そのため複合材料中に界面剥嚁なと
の僅かな久陥が導入されると，荷重に平行方向の熹脚張 係数の変化が強調される.よってこの方向の熟脚張係数 の実験値が理論颠と異なるのは，このような何らかの久 陥が材料内に含まれているためと考えられる。

\section{3 ヤング案}

複合材料全体のヤング率 $E_{L}$ は次式より計算した。

$$
E_{L}=\frac{E_{m}}{1+E_{m} / \sigma_{0} / V_{D} \int_{\Omega} e^{\cdot d V}}
$$

ここで $E_{m}$ はマトリックスのヤング率である， $E_{L}$ 解析に は，次式に示した外部から応力 $\sigma_{0}$ をえた時の分散相内 部の応力とひずの関係から eigenひずみ

$$
\begin{aligned}
& \sigma_{i j}^{0^{\prime}}+\sigma_{i j}{ }^{\prime}=C_{i j k l}^{f}\left(e_{k j}^{j^{\prime}}+\bar{e}_{k l}{ }^{\prime}+e_{k j}\right) \\
& =C_{i j k l}\left(e_{k l}^{0}+\bar{e}_{k l}+e_{k j}-e_{k j}{ }^{\prime}\right)
\end{aligned}
$$

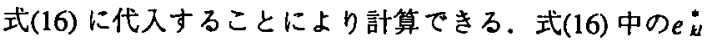
の積分は, 式(15)より分散相の配向性を考虑して求めら れる。

Fig.3の曲線はヤング率の解析結果である。この場合に も熟膨張係数と同様に，分散相が一方向配列した場合， および分散粒子の配向分布を考虑した場合の 2 通りの解 析結果を示してある、これより，理論的には僅かである がヤング率にも異方性が生じることがわかる，そして， 荷重に平行方向よりも垂直方向のヤング率が大きくな り，その差はMoとPSZの体積分率がほほ同じ組成で最 大になる。しかし粒子の配向分布を考虑するとその差は さらに小さくなり，ほとんど異方性は生じていない。 よってヤング率は組織の配向性にはとんど影響をうけな いと結論づけられる。測定結果からもヤング率にははと んど異方性が現れていなかった，LFB 超音波顕微鏡はヤ ング率の高精度測定法として優れているにもかかわらず 異方性を検出できなかったのは，解析結果からるわかる ように本複合材料のヤング率の異方性が極めて微少であ ることが挙げられる。また別の原因の可能性として，本 法が局所領域のヤング率を湘定しているため複合材料中 の組織の配向性を必ずしも十分に反映していないことが 挙げられる。しかし，微少な異方性という点で不確かさ は残るものの，理論解析結果は実験値と良く一致してい ることから，本章での解析理論は本複合材料の解析方法 として妥当であると結論づけられる。

\section{4 熱伝導率}

複合材料全体の熹伝導率 $K_{i j}$ は複合材料の䴅流束 $(q)$ お よび温度勾配 $\left(T_{j}\right)$ を用いて $\left(q_{i}\right)=K_{i j}\left|T_{j}\right|$ のように表され，

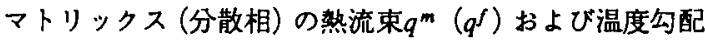


$q^{m}\left(T^{f}\right)$ と分散相の体積分率 $V_{f}$ を用いて次式のように表 される。

$$
|q|=K^{m} \delta_{i j}\left(T_{j}\right)+V_{f}\left(K_{i j}^{f}-K^{f} \delta_{i j}\right)\left(T_{j}^{f}\right)
$$

$\check{2}$

$$
\begin{aligned}
& \left\langle T_{i}^{f}\right\rangle=T_{i}^{0}+S_{i j} T_{j}^{*}-\frac{1}{V_{D}} \int_{\Omega}\left(S_{i j}-I_{i j}\right) T_{i}^{*} \mathrm{~d} V \\
& \left\langle T_{i}\right\rangle=T_{i}^{0}+\frac{1}{V_{D}} \int_{\Omega} T_{i}^{*} \mathrm{~d} V
\end{aligned}
$$

である。ここで $S_{i j}$ は熱伝導率のEshelbyテンソル， $T_{j}{ }^{0}$ は 外部から与えられる一定のボテンシャル勾配， $T_{j}^{*}$ は熟伝 導率の一種の eigen ひずみであり，分散相内部の熱伝導に 関する次式を用いて求めることができる.

$$
\begin{aligned}
q_{i}{ }^{\prime}+q^{0^{\circ}} & =K_{v}^{f}\left(T_{j}^{0^{\circ}}+\bar{T}_{j}{ }^{\prime}+T_{j}^{c^{\prime}}\right) \\
& =K^{m} \delta_{i j}\left(T_{j}{ }^{\circ}+\bar{T}_{j}{ }^{\circ}+T_{j}^{c^{\prime}}-T_{j}^{*^{\prime \prime}}\right)
\end{aligned}
$$

$T_{j}^{*}$ の積分は, 式(15)から求められる.

Fig.4の曲線はホットプレス荷重方向に平行および垂直 方向の熟伝導率の解析結果である。測定値は，試験片作 製の都合上ホットプレスに平行な方向についてのみ得ら れている. 解析には分散粒子のアスベクト此のみ考虑し た場合および配向分布も考虑した場合について行った。 その結果，理論的にも熟伝導率に異方性が現れ，ホット プレスに垂直方向の熱伝導率が平行方向より大きくなる ことがわかった，粒子の配向分布を考虑した場合にはヤ ング率や熹膨張係数の場合とは異なる挙動を示し, PSZ がマトリックスになる組成では，熟伝導率が小さいPSZ マトリックス中に熱伝導率が大きいMoが分散している ため，分散相の配向分布を考虑すると複合材料全体の熟 伝導率は小さくなった。しかし Moがマトリックスにな ろ組成では，分散粒子が配向することによって複合材料 全体の熟伝導率は大きくなるまた，粒子の配向分布が 熱伝導率の異方性に及ほす影響も大きく，一方向整列型 では複合材料全体の熟伝導率に大きな異方性が生じてい るにもかかわらず，分散粒子の配向生に分布が僅かでも 生しると熟伝導率の異方性は極めて小さくなった。また 実験値はホットフレス荷重方向に平行な方向についての み得られたがこの值は解析結果とよく一致しており， 粒子のアスペクト比および配向分布を考虑したモデをを 用いた解析は実験で得られた熱伝導率の挙動を説明する のに適切であることがわかった。
5 まとめ

ホットブレスて作製した Mo/PSZ 系娔結複合材料の 熱・機械的性孟の異方性を測定し、組織観察により定量 化した組織の異方性を代入してEshelby法を用いて理論解 析し比較検討した結果，以下のような結論が得られた。

（1）ホットプレスで作製した Mo/PSZ 系焼結複合材料 の熟膨張係数には大きな異方性が現れ，最大でホットプ レスに平行方向の熱膨張係数が垂直方向に比べ約 $1.5 \times$ 10-6/K大きくなった。一方，ヤング率にははとんど異方 性は現れなかった。

（2）上記の原因を理論的に調べるため，光学影微鏡組 織の画像処理により分散相の配向分布を測定し，得られ たデータを 9 次の多項式分布関数に定量化して理論解析 した．その結果，実際の焼結組織に即した配向分布関数 を適用させたモデルを用いたため，実験結果とよい一致 が見られた．さらに本法は，従来法に比べ多様な組織の 配向分布に正確に対応できるため，敞密解を要求される ような理論解析を行うのに有用であると考えられる。

\section{部}

超音波顕微鏡によるヤング率測定にご協力頂いた東北 大学工学部材料加工学科の伊達和博教授, 三原, 毅助教 授に謝意を表します。

\section{文 献}

1) J. D. Eshelby: Proc. R. Soc., London, A241 (1957) 376.

2) J. D. Eshelby: Proc. R. Soc., London, A252 (1959) 561.

3) T.Mihara, M.Obata: Experimental Mechanics,32 (1992)30.

4) 江 莞, 川崎亮, 伊達和博, 渡辺龍三：日本金属学 会誌, 26 (1977) 527.

5) 渡辺龍三，鈴木英夫，島田平八：粉体および粉末治 金, 33 (1986) 835.

6) 鈴木英夫，太田純一，島田平八，渡辺龍三：粉体お よび粉末绐金, 33 (1986) 418.

7) 川崎亮, 渡辺龍三, 島田平八：日本金属学会誌, 50 (1986) 1056.

8) M. L. Dunn, M. Taya: J. Mater. Sci., 29 (1994) 2053.

9) Y.Takao, T.W.Chou, M.Taya: Trans.ASME,49 (1982)536.

10) T. Mori, K. Tanaka: Acta Metall., 21 (1973) 571. 